\title{
Faces Immediate
}

National Cancer Institute

\section{Source}

National Cancer Institute. Faces Immediate. NCI Thesaurus. Code C120329.

A component of the Children's Memory Scale. A series of faces are presented one at a time. The child is then asked to say yes or no if the face being presented was one of the faces from the initial list. 